\title{
Clinical aspects of male germ cell apoptosis during testis development and spermatogenesis
}

\author{
Leo Dunkel ${ }^{1,2}$, Virve Hirvonen ${ }^{1}$ and Krista Erkkilä ${ }^{1}$ \\ ${ }^{1}$ Children's Hospital, University of Helsinki, SF-00290 Helsinki, Finland \\ 2 corresponding author: Dr. Leo Dunkel, MD Children's Hospital, University of \\ Helsinki, SF-00290 Helsinki, Finland. tel: int+358-0-4711; fax: int+358-0- \\ 4714700; e-mail: leo.dunkel@sci.fi
}

\begin{abstract}
Abbreviations: hCG, human chorionic gonadotropin; $\mathrm{LH}$, leutinizing hormone; $\mathrm{FH}$, follicle stimulating hormone; $\mathrm{GnRH}$, gonadotropin-releasing hormone; WHO, World Health Organization; EDS, ethane dimethane sulfonate; TNF, tumor necrosis factor; TRPM-2 testosterone repressed prostrate message-2
\end{abstract}

\section{Introduction}

Only few studies are presently available regarding germ cell apoptosis in the human testis. It is widely accepted, however, that in all species apoptosis plays a major role in spermatogenesis. The role of apoptosis in disorders of spermatogenesis remains to be established. The present work reviews studies performed in our laboratory to evaluate the occurrence of apoptosis in cryptorchid testes. Furthermore, the effect of changes in serum androgen levels following treatment of cryptorchidism with human chorionic gonadotropin (hCG) in scrotal and cryptorchid testis biopsies of prepubertal boys were evaluated.

In the second part of this review the role of germ cell apoptosis in regulation of germ cell number during spermatogenesis is discussed. We also discuss the essential role of androgens as germ cell survival factors during spermatogenesis in adult human testis.

\section{Germ cell number in the human testis during development}

Serum concentrations of FSH, LH (Winter et al, 1975), and testosterone (Forest et al, 1973) are transiently elevated during the first 6 months of postnatal life. At the same time, the total number of testicular germ cells increases closely paralleling the changes in serum gonadotropin and androgen levels (Muller et al, 1984) (Figure 1). Subsequently, the number of testicular germ cells decreases, reaching the lowest count per tubule by the age of 2 years, and followed by a gradual increase during the prepubertal period. At the onset of puberty, the number of spermatogonia per tubule rapidly increases concomitantly with an increase in serum gonadotropin and androgen concentrations, an increase in tubular diameter, and the onset of active spermatogenesis (Hadziselimovic et al, 1987).

In prepuberty, two maturational steps have been described in the germ cells. The first step is the transformation of gonocytes into spermatogonia, which is usually complete by 6 months of age. In normal testes, the histomorphometric features of this transformation are a steady decrease in the number of gonocytes from birth until they disappear entirely at about 3 months of age. Simultaneously, a steady increase is observed in the number of spermatogonia, so that by 3 months of age 
most biopsies contain spermatogonia (Hadziselimovic et al, 1986; Huff et al, 1991). It has been suggested that spermatogonia are the stable pool of stem cells that continuously replenish the supply of germ cells throughout the rest of life (Clermont, 1996). The second of the two prepubertal steps in the maturation of germ cells in human testis is the transformation of spermatogonia into primary spermatocytes, which normally begins at approximately 3 years of age. The morphometric feature of this step in normal testes is the appearance of primary spermatocytes while the number of spermatogonia remains stable (Huff et al, 1989). The changes in germ cell number are closely associated with changes in serum gonadotropin and androgen concentrations. The germ cell number in the human testis is controlled by apoptosis during development.

\section{Increased apoptotic germ cell death in the cryptorchid human testis}

Cryptorchidism is the most common congenital disorder in newborn boys. The incidence of cryptorchidism has increased

\section{GONADOTROPIN CONCENTRATIONS}

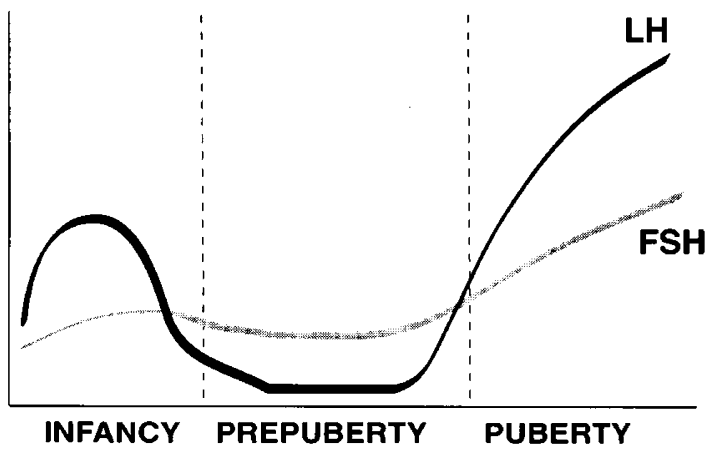

NUMBER OF GERM CELLS / TUBULE

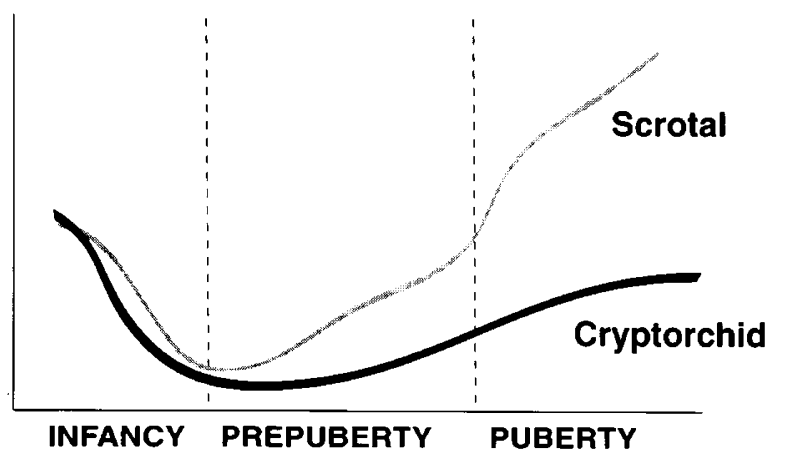

Figure 1 A schematic presentation of the interrelationships between gonadotropin levels and testicular germ cell counts during development (infancy $0-1$ years; prepuberty $1-10$ years; puberty 10 years). In cryptorchidism the germ cell counts are within normal limits during the first year of life and fall below the normal range between 1-2 years of age. The figure is based on data from Forest et al, 1973; Winter et al, 1975; Muller et al, 1984 and Hadziselimovic et al, 1987. during the last few decades (John Radcliffe, 1992) from about $1 \%$ to $1.5 \%$. It is a serious risk factor for testicular cancer (Martin, 1982) and an important cause of infertility (Kogan, 1987).

The pathogenesis of the reduced fertility seen in cryptorchidism has not been fully clarified. Several studies have detailed the morphometric features of cryptorchid testes during the early years of life (Hedinger, 1982; Huff et al, 1989; Schindler et al, 1987). The germ cell counts of cryptorchid testes are within normal limits during the 1st year of postnatal life. They fall below the normal range between 1 and 2 years of age, reaching the lowest level of germ cells per tubule at approximately 2 years of age (Hedinger, 1982; Huff et al, 1989; Schindler et al, 1987) (Figure 1). The reduced fertility has been linked to the reduced number of germ cells, because the cryptorchid patients with the lowest total germ cell counts have the poorest spermiograms in adulthood (Hadziselimovic et al, 1987).

The unfavorable temperature affecting the undescended testis may also be an important factor in the occurrence of germ cell loss and infertility. The temperature in the scrotum, which is a few degrees lower than the body temperature, is believed to maintain an optimal environment for testicular function. Surgical induction of cryptorchidism in experimental animals causes disruption of spermatogenesis, which leads to infertility (Nelson, 1951). Furthermore, surgically induced cryptorchidism in the immature rat testis is followed by a time-dependent, $2-4$ fold increase in DNA cleavage into the low molecular weight fragments characteristic of apoptosis. The cell type affected by induced cryptorchidism appears to be the primary spermatocyte (Shikone et al, 1994).

\section{Treatment of cryptorchidism with hCG results in increased apoptotic germ cell death and deteriorated testis function}

It has been shown that the germ cell death in the rodent testis takes place through the process of apoptosis (Tapanainen et al, 1993; Billig et al, 1995). This process is closely controlled by gonadotropins and androgens (Tapanainen et al, 1993; Billig et al, 1995; Sinha Hikim et al, 1995; Henriksen et al, 1995). It is also known that hCG treatment transiently increases serum androgen concentrations by about 150 -fold, i.e. to the levels seen in adult men (Dunkel et al, 1985), followed by a gradual decrease over several weeks. Therefore we decided to study the effects of the dramatic changes in serum androgen levels following treatment of cryptorchidism with hCG on germ cell death and testis development.

We evaluated the occurrence of apoptosis in the scrotal and cryptorchid testes of 73 prepubertal boys, 43 of whom had received hCG treatment, which consisted of 10 injections over a period of 5 weeks (Heiskanen et al, 1996). A single dose for patients less than 12 months was $250 \mathrm{IU}$, for patients under 7 years, $500 \mathrm{IU}$, and for patients over 7 years, $1000 \mathrm{IU}$. The ages of the patients ranged from 11 months to 11 years (mean 5.2 years). A total of 102 testis biopsies were examined. With the in situ $3^{\prime}$ end- 
labeling technique, the apoptotic cells in the seminiferous tubules were identified as being exclusively spermatogonia (Figure 2A). These apoptotic spermatogonia appeared as single cells in both the scrotal and the cryptorchid testes.
Overall, when the number of apoptotic spermatogonia was expressed per square millimeter of tubular area, the scrotal testes contained more apoptotic spermatogonia than the cryptorchid ones. The higher number of apoptotic
A

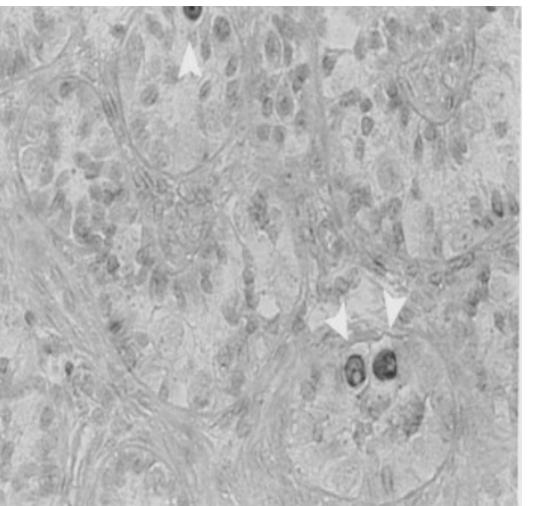

B Apoptotic vs. non apoptotic
spermatogonia $(\%)$

cryptorchid scrotal

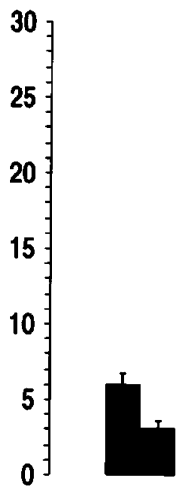

No hCG

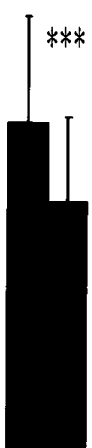

After hCG treatment
C

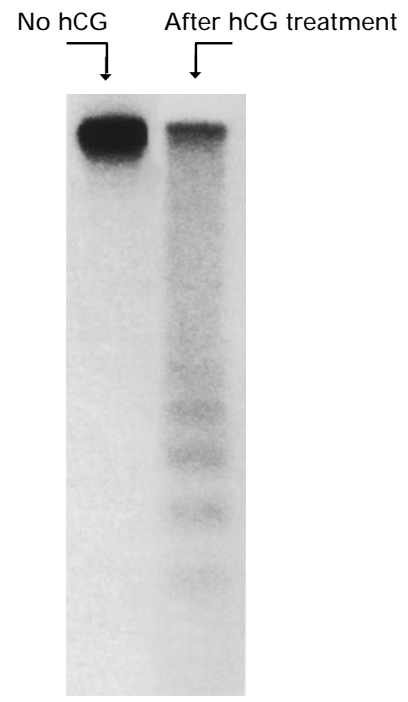

Figure 2 Apoptotic cell death in situ in the germ cells of the human testis in prepuberty. (A) A representative testicular biopsy from a scrotal testis of a 5-year-old boy is shown. The histological sections were stained with an in situ $3^{\prime}$ end-labeling technique in which the digoxigenin-ddUTP label is detected by digoxigenin antibodies conjugated with alkaline phosphatase. Arrows indicate apoptotic cells, which were exclusively spermatogonia. (B) The percentage of apoptotic spermatogonia in the scrotal $(n=33)$ and cryptorchid $(n=69)$ testes of prepubertal boys. The total number of spermatogonia was decreased in the cryptorchid testes. However, the percentage of apoptotic spermatogonia was increased, suggesting that in cryptorchidism, the accelerated decrease in the number of spermatogonia is due to increased level of apoptosis. hCG treatment dramatically increased the number of apoptotic cells $\left({ }^{* * *} ; \mathrm{p} \times 0.01\right)$. Values are mean+SEM. (C) The specificity of the apoptotic staining in situ in selected biopsies. The typical ladder pattern indicates the extent of DNA fragmentation, consistent with numbers of stained cells. For this detection technique, one microgram of DNA from each biopsy sample was isolated before labeling its $3^{\prime}$ ends with radioactive (a-32P) dideoxy-ATP. The DNA samples were then loaded on agarose gels and separated by electrophoresis. Evidence of apoptosis, indicated by the occurrence of internucleosomal DNA breakdown into 185-basepair (bp) multiples, is observed.

\section{Testis volume}

\section{Normal \\ D. Subnormal}

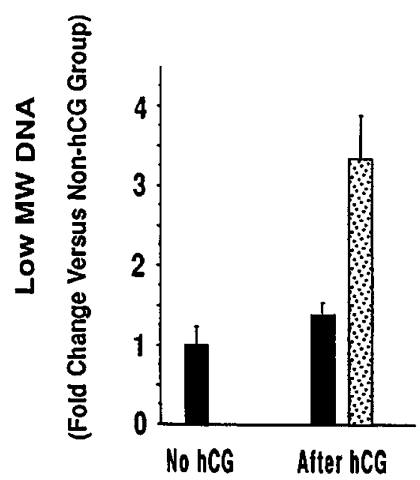

\section{Sperm density}

Normal

R Subnormal

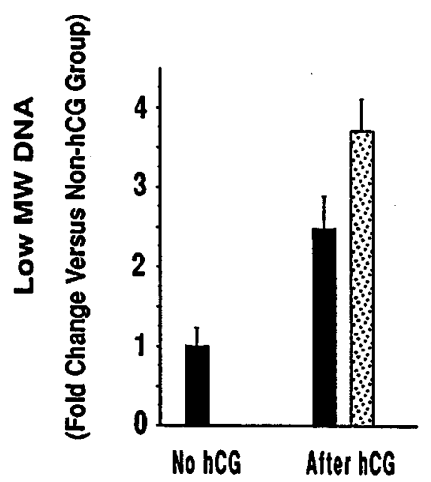

\section{Serum FSH}

Figure 3 The outcome of hCG treatment-induced apoptotic DNA fragmentation. The relative levels of low molecular weight DNA fragmentation are shown for patients who were treated for cryptorchidism either operatively only (No hCG, $n=10$ ) or operatively after preceding unsuccessful treatment with hCG (After hCG, $n=15$ ) in prepuberty. The hCG-treated patients were subdivided according to normal or pathological values for testis volume, sperm density or serum FSH levels in adulthood. The clear differences in low molecular weight DNA between the two groups indicates that the level of DNA fragmentation in prepuberty predicts testis function in adulthood. Values are mean+SEM. 
spermatogonia in the scrotal than in the cryptorchid testes was due to the lower number of spermatogonia in the cryptorchid testes, as evidenced by the higher percentage of apoptotic spermatogonia in the cryptorchid testes than in the scrotal testes (Figure 2B). Analysis of the hCG treatment demonstrated that 1-4 weeks after hCG treatment the number of apoptotic cells had increased significantly as compared with the non treated group (Figure 2B and $\mathrm{C}$ ).

Having found increased apoptotic germ cell death after hCG treatment of cryptorchidism in testis biopsy specimen taken more than 20 years ago, we assessed the possible long-term consequences of the hCG treatment-induced germ cell death in prepuberty on reproductive functions in adult life.
We studied 25 of the same cryptorchid patients now in their adulthood. Fifteen of these had received unsuccessful hCG therapy before orchidopexy and the remaining ten patients had been treated with orchidopexy alone. Apoptosis detected in testis biopsies taken in prepubertal life was correlated with various parameters of testicular function in adult life. Sperm was collected after a minimum of 2 days of abstinence. Semen analysis was done within $2 \mathrm{~h}$ and interpreted according to the World Health Organization criteria (WHO, 1992); sperm density was considered normal, when the sperm concentration was at least $20 \times 106$ spermatozoa/ml. From each patient, the baseline serum $\mathrm{FSH}, \mathrm{LH}$, testosterone and prolactin levels were quantified using conventional radioimmunoassays.

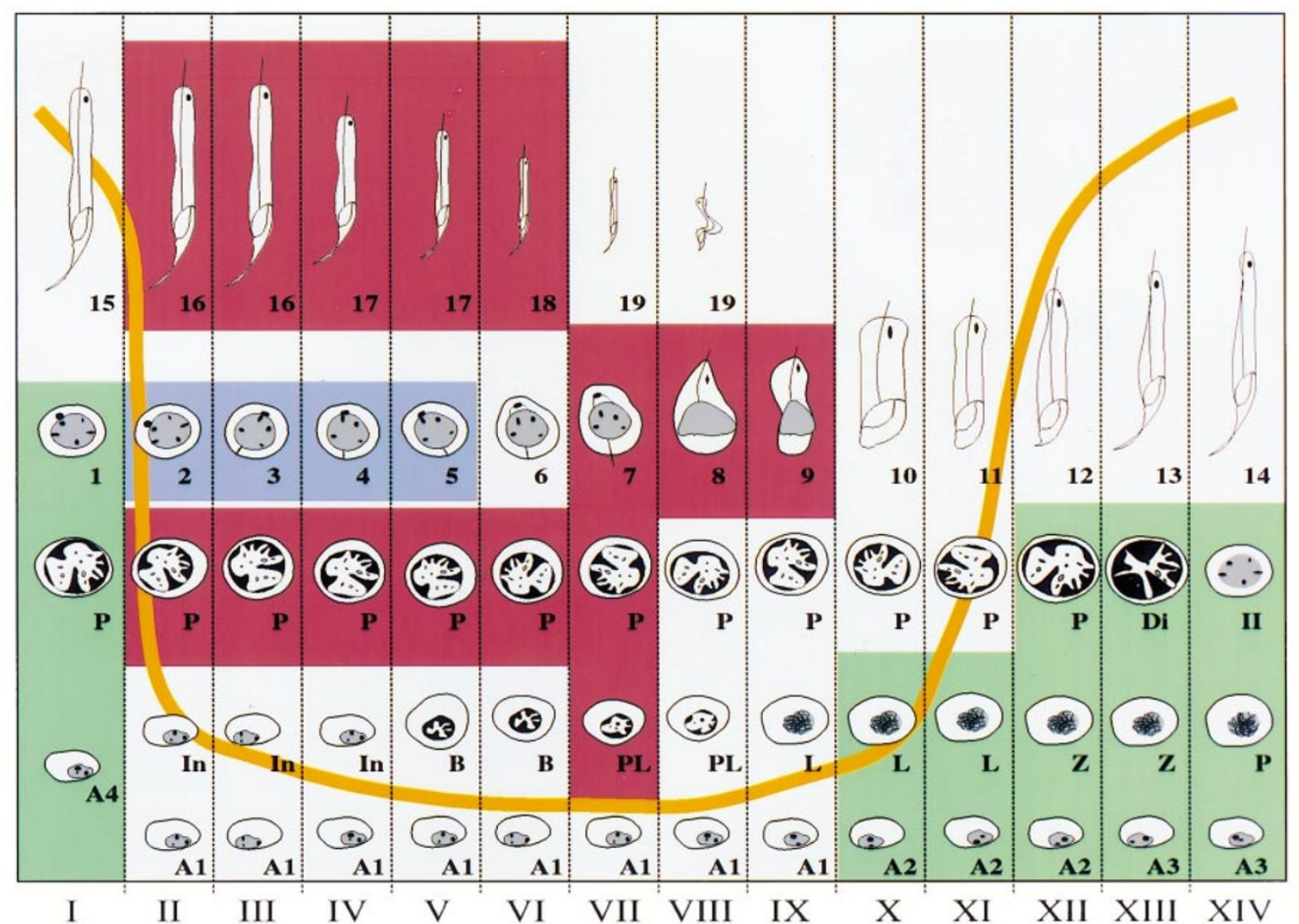

Germ cells sensitive to undergo spontaneous apoptosis

Relative quantity of spontaneous apoptosis

Germ cells sensitive to undergo apoptosis after testosterone withdrawal

In early round spermatids FSH promotes cell survival

Figure 4 Summary diagrams of the distribution of the type of germ cells undergoing degeneration in the rat testis. The green areas represent the presence but not the number of spontaneously degenerating cells, the yellow line represents the relative level of apoptosis in various stages of the spermatogenic cycle. The germ cells most susceptible to testosterone withdrawal induced by EDS treatment (red areas). In round spermatids apoptotic cell death is prevented by FSH (blue areas). Modified from (Henriksen et al, 1995; Henriksen et al, 1996). 
Quantification with low molecular weight DNA ( $<10 \mathrm{~kb})$ showed that testicular DNA from boys who had not received hCG treatment for cryptorchidism showed very low levels of DNA fragmentation. In contrast, the amount of low molecular weight DNA in samples taken after hCG treatment was 2.9-fold as compared with the samples without prior hCG treatment $(p<0.001)$.

About 20 years after the biopsy, the volume of the cryptorchid testis was smaller in the hCG-treated group than in the non-treated group $(12.7 \pm 0.8 \mathrm{~mL}$ versus $9.4 \pm 0.9 \mathrm{~mL}, p<0.01)$. The sperm densities were also lower and the FSH levels higher in the patients with excessive apoptosis in spermatogonia following treatment with hCG. The level of DNA fragmentation detected in testis biopsies taken in prepuberty predicted well the outcome of the testis function. Among the patients who had received hCG treatment for cryptorchidism in prepuberty, those who had subnormal testis volumes, subnormal sperm density, or pathologically elevated serum $\mathrm{FSH}$ levels had had significantly more apoptotic DNA fragmentation after hCG treatment (Figure 3). These data suggest that the development of the testis may be severely disrupted by hCG treatment-induced germ cell apoptosis.

\section{Germ cell degeneration and apoptosis during spermatogenesis}

In the rodent testis, multiplication of germ cells in the testis is always accompanied by degeneration of some of the proliferating cells. During spermatogenesis germ cell death occurs spontaneously at various phases of germ cell development, and in consequence the seminiferous epithelium yields fewer spermatozoa than would be anticipated from spermatogonial proliferations (Clermont,
1962; Huckins, 1978; Wing et al, 1982). Germ cell deletion during normal spermatogenesis has been estimated to result in the loss of up to $75 \%$ of the potential numbers of mature sperm cells in the adult testis (De Rooij et al, 1987; Huckins, 1978; Oakland, 1956). Detailed analyses of germ cell degeneration have been published (Allan et al, 1992; Clermont, 1962; De Rooij and Lok, 1987; Huckins, 1978; Kerr, 1992; Wing and Christiansen, 1982); morphometric analyses of semithin sections of perfusion-fixed testes have indicated that the loss of germ cells in the rodent testis is greatest during the mitoses of type A2, A3, and A4 spermatogonia and during the first meiotic division (Figure 4). No degeneration occurs in type A1 spermatogonia, or in intermediate or type B spermatogonia (Johnson et al, 1984; Kerr, 1992) (Figure 4). The mitotic and meiotic divisions take place at distinct stages of the cycle of the seminiferous epithelium (often referred to as spermatogenic cycle). Therefore, spontaneously degenerating cells can normally be found only at certain stages: at stages IIVII few if any cells degenerate, whereas stages XIII-I show considerable germ cell degeneration (Johnson et al, 1984; Kerr, 1992; Wing and Christiansen, 1982) (Figure 4).

Although the degeneration of testicular germ cells was originally characterized more than a century ago (Flemming, 1887), it was only recently discovered how the cells die. On the basis of morphological evidence, it was first suggested that cell death of spermatogonia during normal spermatogenesis takes place through the apoptotic mechanism, the spermatocytes and spermatids, in contrast undergoing necrosis (Allan et al, 1992). Recently, however, quantification of small molecular weight DNA fragments and in situ DNA 3'end-labeling analyses of apoptosis in the testis have shown that spermatocytes and spermatids can also undergo apoptosis (Billig et al, 1995; Henriksen et al,
A

\section{Relative level of germ cell apoptosis}

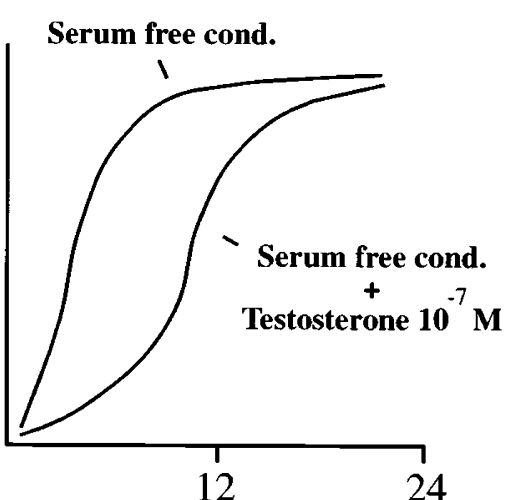

B

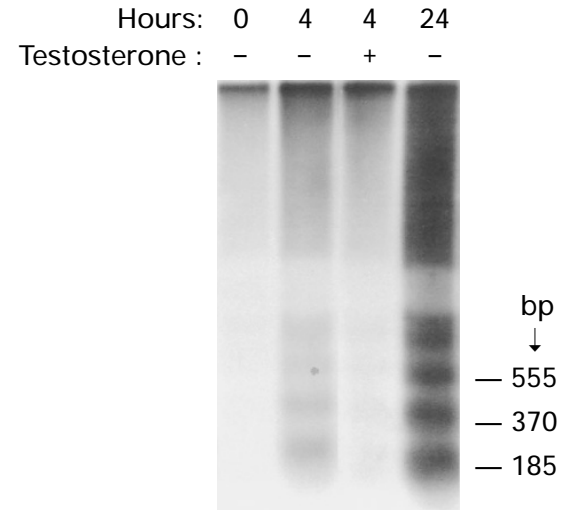

\section{Hours in culture}

Figure 5 Testosterone-mediated inhibition of apoptosis induced in human seminiferous tubules cultured in serum-free conditions. Small tissue sections of seminiferous tubules from adult human testis were isolated and incubated under serum-free conditions in the absence or presence of testosterone. After incubation, small tissue sections were snap-frozen in liquid nitrogen, DNA was extracted, $3^{\prime}$ end-labeled with digoxigenin-ddUTP, and fractionated through agarose gels. Apoptosis was revealed by low mol wt DNA fragmentation (185 bp multiples) in Southern blot analysis. Low mw DNA (<1.3 kb) quantification was performed by using the MCID Image Analyzing System. (A) Relative level of germ cell apoptosis. The extent of low mw DNA ( $y$-axis) is expressed relative to the levels at the beginning of the experiment (time $0 \mathrm{~h}$ ). (B) The spontaneous apoptotic DNA laddering became more intensive as the incubation time in serum-free conditions increased. The spontaneous apoptosis was suppressed by testosterone only in short-term incubations. $(n=3)$. 
1995; Sinha Hikim et al, 1995). During normal spermatogenesis, apoptosis has been shown to take place in the very same cells and stages in which germ cell degeneration was previously observed (Billig et al, 1995; Henriksen et al, 1995) (Figure 4), indicating that germ cell degeneration is in fact apoptotic cell death.

The physiological significance of germ cell apoptosis is as yet unclear. It may be a means for regulating the number of differentiating spermatogonia to meet the capacity of the Sertoli cells to support the developing germ cells. The outcome of this regulation would be a constant number of meiotic cells. Since Sertoli cells do not divide in adulthood and are able to support only a certain number of germ cells at a time, the number of spermatogonia entering meiosis must be limited. Apparently, when too many spermatogonia are formed, the surplus cells degenerates (De Rooij et al, 1987), most likely by apoptosis.

\section{Hormonal regulation of germ cell apoptosis during spermatogenesis}

Russel and Clermont (Russel et al, 1977) have shown that the first cells to generate after hypophysectomy in adult rats are primary spermatocytes and spermatids at stage VII of the spermatogenic cycle. FSH does not inhibit this degeneration, whereas LH or, more efficiently, a combination of FSH and $\mathrm{LH}$, is able to prevent the damage. These data suggests that androgens (stimulated by $\mathrm{LH}$ ) are indispensable for the maintenance of spermatogenesis. Extensive evidence supporting this concept has been accumulated since the 1970s (for review see Sharpe, 1994).

More recently it was reported that in the immature rat testis, hypophysectomy and treatment with gonadotropinreleasing hormone $(\mathrm{GnRH})$ antagonist results in a marked increase in apoptosis (Tapanainen et al, 1993). Supplementation with FSH agonist, hCG, or testosterone partially inhibits apoptotic DNA cleavage. The role of testosterone in inhibition and induction of apoptosis in the immature rat testis was recently further clarified by in situ quantification of squash preparations (Henriksen et al, 1995) Destruction of Leydig cells with ethane dimethane sulfonate (EDS) in vivo resulted in rapid apoptosis of Leydig cells and a subsequent decrease in both serum and intratesticular testosterone concentrations. The reduction in androgen induced a significant increase in the number of apoptotic cells in the seminiferous tubules at stages $I I-X \mid$ of the spermatogenic cycle, primarily affecting the pachytene spermatocytes in stages II-VIII, and step 16-18 spermatids in stages II-VI (Figure 4). Interestingly, testosterone seemed to be a positive regulator of apoptotic germ cell death at stage XII. (Henriksen et al, 1995).

The role of FSH during spermatogenesis is not clear. The main target cells for FSH are considered to be the Sertoli cells via which the action of FSH is signalled. In the adult rat FSH is suggested to be needed for the maintenance of spermatogenesis whereas in the immature rodent $\mathrm{FSH}$ is required also for the initiation of spermatogenesis (Tapanainen et al, 1993). Mouse (Haneji et al, 1984) and immature rat (Boitani et al, 1993) spermatogonia were stimulated by $\mathrm{FSH}$ in an in vitro model. In vivo the spermatogonia of the juvenile (Arslan et al, 1993) and adult non-human primate (van Alphen et al, 1988) were stimulated by $\mathrm{FSH}$. The number of type B spermatogonia seemed to be regulated by the action of FSH (Sharpe, 1994). In an in vitro model of adult rat germ cell apoptosis FSH prevented apoptosis of seminiferous epithelial cells in a stage-stage specific manner. Apoptosis of round spermatids and pachytene spermatocytes was inhibited by FSH (Henriksen et al, 1996).

On the basis of quantifications of DNA fragmentation, a gradual increase in apoptosis has been observed in the testis cells of juvenile (16 to 28 -day old) rats as compared

A

A1

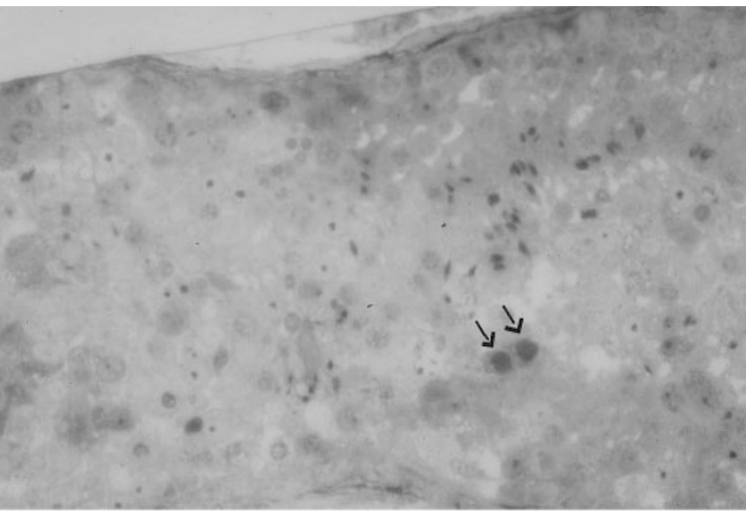

A2

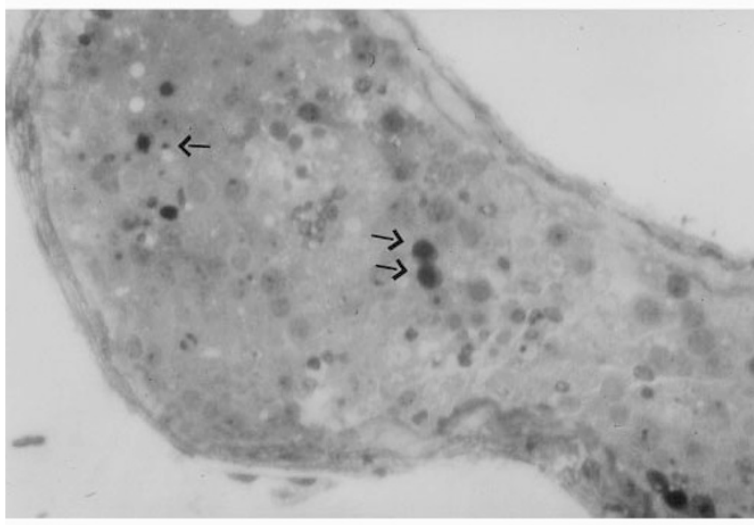

A3

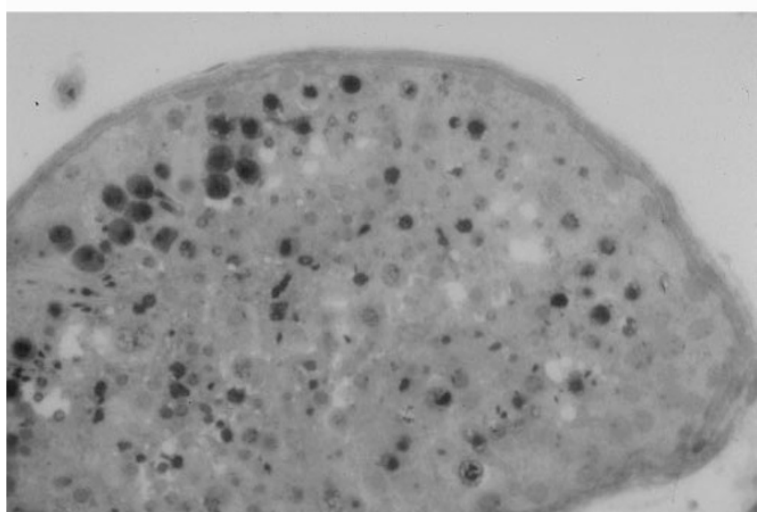


with neonatal (8-day old) animals, followed by a decrease in adult animals (Billig et al, 1995).

Taken together, the studies referred to above have shown that at least three factors determine the onset of apoptosis in male germ cells: (1) lack of hormones, especially gonadotropins and androgens; (2) the specific stage in the spermatogenic cycle; (3) the developmental stage of the animal.

\section{Germ cell apoptosis in human testis during spermatogenesis}

The results discussed above regarding apoptosis in the rodent testes appear to be consistent with our recent findings in the human. To evaluate the role of apoptosis in human testes we incubated small tissue sections of seminiferous tubules from human testis. The samples were obtained from three adult men undergoing orchiectomy for testis cancer. The patients were otherwise healthy and had not had any medication before the operation. The operations were performed at the Department of Urology, University of Helsinki, Finland. The tissue was taken from the non-cancer area of the testes. Small tissue sections, that were dissected under a transillumination microscope, were incubated under serum-free conditions for 0,4 and $24 \mathrm{~h}$ in the absence or presence of testosterone. The incubations were performed at $34^{\circ} \mathrm{C}$ in a humidified atmosphere containing $5 \% \mathrm{CO}_{2}$.

After incubation, the small tissue sections of seminiferous tubules were snap-frozen in liquid nitrogen, DNA was extracted, 3' end-labeled with digoxigenin-ddUTP, and fractionated through agarose gel (1000 ng/lane). Apoptosis was revealed by low mol wt DNA fragmentation (185 bp multiples) in Southern blot analysis (Figure 5). Low $\mathrm{mw}$ DNA $(<1.3 \mathrm{~kb})$ quantification was performed by using the MCID Image Analyzing System. The apoptotic laddering

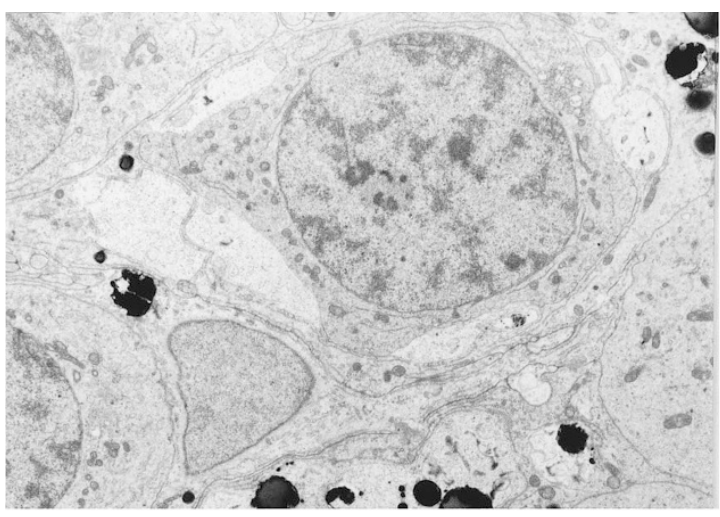

B1

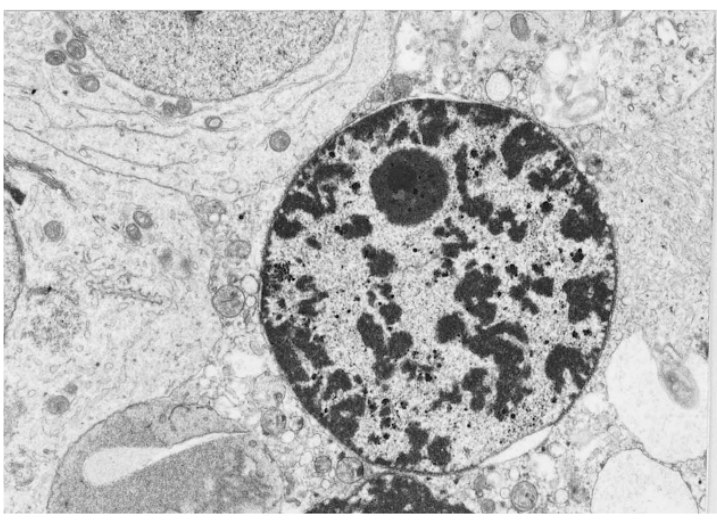

B2

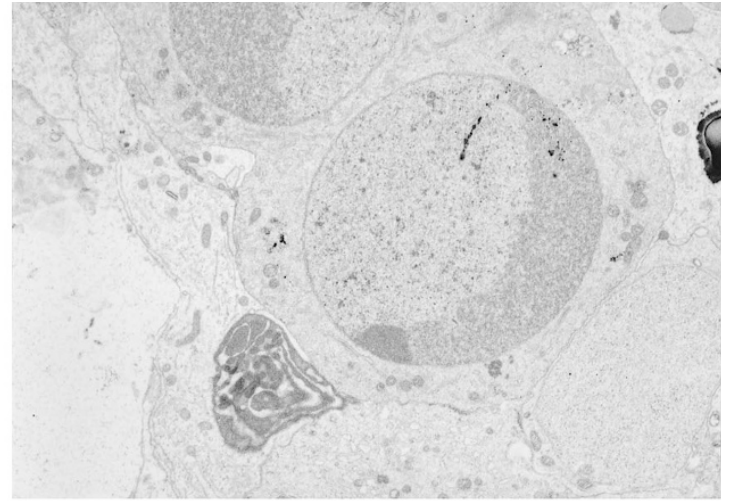

B3

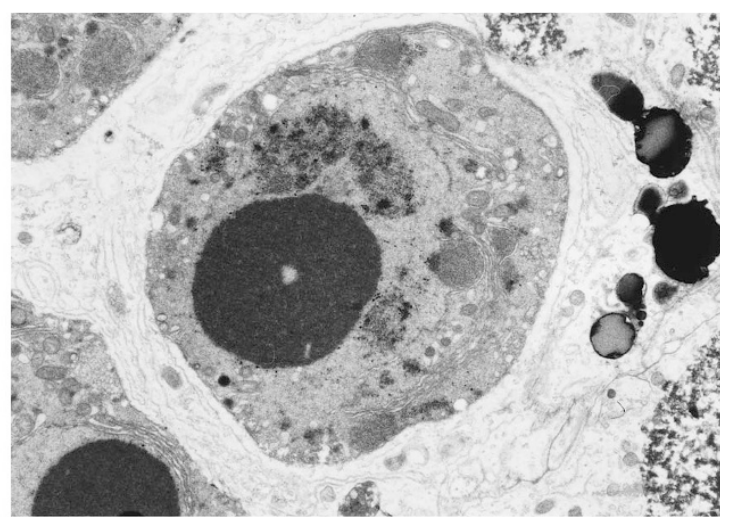

B4

Figure 6 Morphological analysis of apoptosis in adult human testis tissue. To induce spontaneous apoptosis small tissue sections of seminiferous tubules from adult human testis were isolated and incubated under serum-free conditions. The small tissue sections of seminiferous tubules were fixed in glutaraldehyde. (A) Toluinide blue stained segments of seminiferous tubules were analyzed under the light microscope. The morphological signs of apoptosis (arrows) were mostly seen in spermatocytes (A1, A2, A3). Some spermatids also showed signs of apoptosis. Some of the cells that were in late stage of apoptosis could not be identified. Consistent with the results of DNA fragmentation analysis, a time-dependent increase in morphological apoptosis was observed $(\mathbf{A} 1=0 \mathrm{~h}, \mathbf{A} 2=4 \mathrm{~h}, \mathbf{A} 3=24 \mathrm{~h})$. $(\mathbf{B})$ The further confirmation of the apoptotic nature of cell degeneration was done by electron microscopy. Small clumps of heterochromatin could be distinguished in the nuclei of the cells in early stages of apoptosis. In later stages of degeneration the areas of heterochromatin became larger. Condensated chromatin and irregular pattern of organelles were seen in the latest stages of apoptosis. Morpholigical signs of apoptosis were most frequently identified in spermatocytes and occasionally in some spermatids. B1: normal spermatocyte; B2: apoptotic spermatocyte: B3: apoptotic spermatid with crescent-like condensation of chromatin; B4: late apoptosis, cell not identifiable (B) B1= $\mathrm{h}, \mathrm{B} 2=4 \mathrm{~h}, \mathrm{~B} 3=4 \mathrm{~h}, \mathrm{~B} 4=4 \mathrm{~h}$ ). 
seen in the Southern blots rapidly increased with incubation time. Spontaneous apoptosis was suppressed by testosterone concentration of 10-7 M for about $4 \mathrm{~h}$ (Figure 5). After $24 \mathrm{~h}$ of incubation the suppressive effect of testosterone could not be observed,

For the morphological analysis of apoptotic cells small tissue sections of seminiferous tubules were fixed in glutaraldehyde. The apoptotic nature of the dying cells was confirmed by morphological signs of apoptosis under light- and electronmicroscopy (Figure 6). Toluinide blue stained segments of seminiferous tubules from human testis were analyzed under the light microscope. Those apoptotic cells that could be identified were mostly spermatocytes. A few spermatids also showed signs of apoptosis.

The further confirmation of the apoptotic nature of cell degeneration was done by electron microscopy. Small clumps of heterochromatin could be distinguished in the nuclei of the cells in early stages of apoptosis. In later stages of degeneration the areas of heterochromatin became larger. Condensated chromatin and irregular pattern of organelles were seen in the latest stages of apoptosis. Morphological signs of apoptosis were most frequently identified in spermatocytes. Occasionally some spermatids also showed signs of apoptosis.

\section{Genes involved in germ cell death}

The members of $b c /-2$ gene family have reported to be involved in the regulation of apoptotic death in various cells via hetero- or homodimeric actions (Hockenbery, 1995). Bcl-2 and $b c /-x L$ function to block programmed cell death. In contrast, bax and $b c /-x S$ have the ability to counter death repressor effects and induce apoptosis (Reed, 1994). There is some evidence that $b c l-x$ and $b c l-2$ are not expressed in spermatogonia (Hockenbery, 1995; Krajewski et al, 1994), but the exact roles of the members of this large gene family have not yet been established in the testis. Disordered seminiferous tubules, an accumulation of atypical premeiotic germ cells and no haploid sperm were characters of bax knockout mice, which were infertile (Knudson et al, 1995). Cell death was accompanied with dysplastic cells and multinucleated giant cells.

Fas ligand (or Apo-1, CD 95) belongs to the TNF (tumor necrosis factor) family. It has reported to induce apoptosis via Fas, its cell surface receptor. Fas ligand, which size is shorter than in other tissues (Suda et al, 1995), is expressed in testes Sertoli cells (Bellgrau et al, 1995). The role of Fas in germ cell apoptosis is unknown.

A tumor suppressor protein, p53, is recognized to take part in the induction of apoptosis (Evan et al, 1995). Following DNA damage the level of p53 increase rapidly and there is an evidence that it is an important component of the G1 arrest during the cell cycle (Kastan et al, 1991; Kuerbitz et al, 1992). p53 protein was immunohistochemically detected in tetraploid pachytene primary spermatocytes (Schwartz et al, 1993). Recently, p53 protein accumulation after exposure to $\mathrm{X}$-rays in mice was investigated. No accumulation of p53 protein was observed in the testis (Wang et al, 1996).
Clusterin (TRPM-2, apolipoprotein J, sulphated glylycoprotein-2) is a protein that is secreted by Sertoli cells and might be associated with apoptosis in testes. The secretion of clusterin in rat testes has been reported to be stage specific (Kangasniemi et al, 1992). It has been proposed to participate in cell-cell interactions (Grima et al, 1992), cellular remodeling and differentiation (Ahuja et al, 1994) as well as programmed cell death in many tissues (Buttyan et al, 1989). There is immunohistochemical data suggesting clusterin to be associated with degenerating germ cells in human testes (O'Bryan et al, 1994).

So far, genes involved in regulation of germ cell death in the human testis have not been defined.

\section{Conclusions}

Our findings lead to the conclusion that apoptosis is controlled by several exogenous factors, e.g. hormones in the human testis. In prepuberty cryptorchidism decreases its occurrence by reducing the number of germ cells capable of undergoing apoptosis. Apoptotic loss of spermatogonia after hCG treatment of cryptorchidism has dramatic long-term consequences. Because of the poor success rates to induce testicular descent, and the negative effects on subsequent reproductive function, the potential long-term hazards of hCG treatment of the testis should be critically re-evaluated.

In adult human testis spontaneous apoptosis can be in vitro induced by incubating small tissue sections of seminiferous tubules under serum-free conditions. Apoptosis is most frequently identified in spermatocytes. Occasionally some spermatids also undergo apoptosis. The role of testosterone in the maintenance of spermatogenesis and in the inhibition of apoptosis in the rodent testes appear to be consistent with the human. The spontaneous germ cell apoptosis induced under serum-free conditions is suppressed by testosterone indicating that testosterone is a critical germ cell survival factor also in the human testis.

\section{References}

Ahuja HS, Tenniswood M, Lockshin Rand Zakeri ZF (1994) Expression of clusterin in cell differentiation and cell death. Biochem. Cell. Biol. 72: 523-530

Allan DJ, Harmon BV and Roberts SA (1992) Spermatogonial apoptosis has three morphologically recognizable phases and shows no circadian rhythm during normal spermatogenesis in the rat. Cell. Prolif. 25: 241-250

Arslan M, Weinbauer GF, Schlatt S, Shahab M and Nieschlag E (1993) FSH and testosterone, alone or in combination, initiate testicular growth and increase the number of spermatogonia and Sertoli cells in a juvenile non-human primate (Macaca mulatta). J. Endocrinol. 136: 235-243

Bellgrau D, Gold D, Selawry H, Moore J, Franzusoff A and Duke RC (1995) A role for CD95 ligand in preventing graft rejection. Nature 377: 630-632

Billig H, Furuta I, Rivier C, Tapanainen J, Parvinen M and Hsueh AJW (1995) Apoptosis in testis germ cells: developmental changes in gonadotropin dependence and localization to selective tubule stages. Endocrinology 136: $5-12$

Boitani C, Politi MG and Menna T (1993) Spermatogonial cell proliferation in organ culture of immature rat testis. Biol. Reprod. 48: 761-767

Buttyan R, Olsson CA, Pintar J, Chang C, Brandyk M, Ng PY and Sawczuk IS (1989) Induction of the TRPM-2 gene in cells undergoing programmed death. Mol. Cell. Biol. 9: 3473-3481

Clermont $Y$ (1962) Quantitative analysis of spermatogenesis of the rat: a revised model for the renewal of spermatogonia. Am. J. Anat. 111: 111-129 
Clermont Y (1966) Renewal of spermatogonia in man. Am. J. Anat. 118: 509-524

De Rooij DG and Lok D (1987) Regulation of the density of spermatogonia in the seminiferous epithelium of the Chinese hamster: II. Differentiating spermatogonia. Anat. Rec. 217: 131-136

Dunkel L, Perheentupa P and Apter D (1985) Kinetics of the steroidogenic response to single versus repeated doses of human chorionic gonadotropin in boys in prepuberty and early puberty. Pediatr. Res. 19: 1-4

Evan GI, Brown L, Whyte M and Harrington E (1995) Apoptosis and cell cycle. Curr. Opin. Cell. Biol. 7: 825-834

Flemming W (1887) Neue Beiträge zur Kenntniss der Zelle: I. Die Kerntheilung be den Spermatocyten von Salamandra maculosa. Archiv. Mikrosk. Anat. Entw. Mach. 29: 389-463

Forest M, Cathiard AM and Bertrand JA (1973) Evidence of testicular activity in early infancy. J. Clin. Endocrinol. Metab. 37: 148-151

Grima J, Pineau C, Bardin CW and Cheng CY (1992) Rat Sertoli cell clusterin, alpha 2macroglobulin, and testins: biosynthesis and differential regulation by germ cells. Mol. Cell. Endocrinol. 89: 127-140

Hadziselimovic F, Herzog B and Buser M (1987) Development of cryptorchid testes. Eur. J. Pediatr. 146 (Suppl 2): 8-12

Hadziselimovic F, Herzog B, Hocht B, Hecker E, Miescher E and Buser M (1987) Screening for cryptorchid boys risking sterility and results of long-term buserelin treatment after successful orchidopexy. Eur. J. Pediatr. 146: 59-62

Hadziselimovic F, Thommen L, Girard J and Herzog B (1986) The significance of postnatal gonadotropin surge for testicular development in normal and cryptorchid testes. J. Urol. 136: 274-276

Haneji T, Maekawa M and Nishimune Y (1984) Vitamin A and follicle-stimulating hormone synergistically induce differentiation of type A spermatogonia in adult mouse cryptorchid testes in vitro. Endocrinology 114: 801-805

HedingerE (1982) Histopathology of undescended testes. Eur. J. Pediatr. 139: 266 271

Heiskanen P, Billig H, Toppari J, Kaleva M, Arsalo A, Rapola J and Dunkel L (1996) Apoptotic cell death in the normal and cryptorchid human testis: the effect of human chorionic gonadotropin on testicular cell survival. Pediatr. Res. 40:351 356

Henriksen K, Hakovirta H and Parvinen M (1995) Testosterone inhibits and induces apoptosis in rat seminiferous tubules in a stage-specific manner: in situ quantification in squash preparations after administration of ethane dimethane sulfonate. Endocrinology 136: 3285-3291

Henriksen K, Kangasniemi M, Parvinen M, Kaipia A and Hakovirta H (1996) In vitro, follicle-stimulating hormone prevents apoptosis and stimulated deoxyribonucleic acid synthesis in the rat seminiferous epithelium in stage-specific fashion Endocrinology 137: 2141-2149

Hockenbery DM (1995) bcl-2, a novel regulator of cell death. Bioassays 17:631-638

Huckins C (1978) The morphology and kinetics of spermatogonial degeneration in normal adult rats: an analysis using a simplified classification of germinal epithelium. Anat. Rec. 190: 905-926

Huff DS, Hadziselimovic F, Snyder HM, III, Duckett JW and Keating MA (1989) Postnatal testicular maldevelopment in unilateral cryptorchidism. J. Urol. 142 $546-548$

Huff DS, Hadziselimovic F, Snyder HMI, Blyth B and Duckett JW (1991) Early postnatal testicular maldevelopment in cryptorchidism. J. Urol. 146: 624-626

John Radcliffe Hospital Cryptorchidism Study Group (1992) Cryptorchidism: a prospective study of 7500 consecutive male births, 1984-8. Arch. Dis. Childh. 67 $892-899$

Johnson L, Lebovitz RM and Samson WK (1984) Germ cell degeneration in normal and microwave-irradiated rats: potential sperm production rates at different developmental steps in spermatogenesis. Anat. Rec. 209: 501-507

Kangasniemi M, Cheng CY, Toppari J, Grima J, Stahler M, Bardin CW and Parvinen M (1992) Basal and FSH-stimulated steady state levels of SGP-2, alpha 2macroglobulin, and testibumin in culture media of rat seminiferous tubules at defined stages of the epithelial cycle. J. Androl. 13: 208-213

Kastan MB, Onyekwere O, Sidransky D, Vogelstein B and Craig RW (1991) Participation of $p 53$ protein in the cellular response to DNA damage. CancerRes. 51: $6304-6311$

Kerr JB (1992) Spontaneous degeneration of germ cells in normal rat testis: assessment of cell types and frequency during the spermatogenic cycle. $\mathrm{J}$. Reprod. Fertil. 95: 825-830
Knudson CM, Tung KS, Tourtellotte WG, Brown GA and Korsmeyer SJ (1995) Baxdeficient mice with lymphoid hyperplasia and male germ cell death. Science 270 : $96-99$

Kogan SJ (1987) Fertility in cryptorchidism. An overview in 1987. Eur. J. Pediatr. 146 $21-24$

Krajewski S, Krajewska M, Shabaik A, Wang HG, Irie S, Fong L and Reed JC (1994) Immunohistochemical analysis of in vivo patterns of $\mathrm{Bcl}-\mathrm{X}$ expression. Cancer Res. 54: 5501-5507

Kuerbitz SJ, Plunkett BS, Walsh WV and Kastan MB (1992) Wild-type p53 is a cell cycle checkpoint determinant following irradiation. Proc. Natl. Acad. Sci. USA 89: $7491-7495$

Martin DC (1982) Malignancy in the cryptorchid testis. Urol. Clin. North. Am. 9: 371 376

Muller J and Skakkebaek NE (1984) Fluctuations in the number of germ cells during the late foetal and early postnatal periods in boys. Acta. Endocrinol. (Copenh) 105: $271-274$

Nantel F, Monaco L, Foulkes NS, Masquilier D, LeMeur M, Henriksen K, Dierich A Parvinen $M$ and Sassone Corsi P (1996) Spermiogenesis deficiency and germcell apoptosis in CREM-mutant mice. Nature 380: 159-162

Nelson WO (1951) Mammalian spermatogenesis: effects of experimental cryptorchidism in the rat and non-descent of the testis in man. Recent Prog. Horm. Res. 6: 29-62

O'Bryan MK, Mallidis C, Murphy BF and Baker HW (1994) Immunohistological localization of clusterin in the male genital tract in humans and marmosets. Biol. Reprod. 50: 502-509

Oakland E (1956) A description of spermatogenesis in the mouse and its use in analysis of the cycle of seminiferous epithelium and germ cell renewal. Am. J. Anat. 99: 391-413

Reed JC (1994) Bcl-2 and the regulation of programmed cell death. J. Cell. Biol. 124 $1-6$

Russel LD and Clermont $Y$ (1977) Degeneration of germ cells in normal, hypophysectomized and hormone treated hypophysectomized rats. Anat. Rec. 187: 347-366

Schindler AM, Diaz P, Cuendet A and Sizonenko PC (1987) Cryptorchidism: a morphological study of 670 biopsies. Helv. Paediatr. Acta. 42: 145-158

Schwartz D, Goldfinger N, Rotter N (1993) Expression of p53 protein in spermatogenesis is confined to the tetraploid pachytene primary spermatocytes. Oncogene 8: 1489-1494

Sharpe RM (1994) Regulation of spermatogenesis. In Knobil E and Neill JD, eds. New York: Raven Press pp. 1363-1434

Shikone T, Billig H and Hsueh AJW (1994) Experimentally-induced cryptorchidism increases apoptotic cell death in rat testis. Biol. Reprod. 51: 865-872

Sinha Hikim AP, Wang C, Leung A and Swerdloff R (1995) Involvement of apoptosis in the induction of germ cell degeneration in adult rats after gonadotropinreleasing hormone antagonist treatment. Endocrinology 136: 2770-2775

Suda T, Okazaki T, Naito Y, Yokota T, Arai N, Ozaki S, Nakao K and Nagata S (1995) Expression of the Fas ligand in cells of T cell lineage. J. Immunol. 154: 38063813

Tapanainen JS, Tilly JL, Vihko KKand Hsueh AJ (1993) Hormonal control of apoptotic cell death in the testis: gonadotropins and androgens as testicular cell survival factors. Mol. Endocrinol. 7: 643-650

van Alphen MM, van de Kant HJ and de Rooij DG (1988) Follicle-stimulating hormone stimulates spermatogenesis in the adult monkey. Endocrinology 123: $1449-$ 1455

Wang X, Matsumoto H, Takahashi A, Nakano T, Okaichi K, Ihara M, Ohnishi T (1996) p53 accumulation in the organs of low-dose X-ray-irradiated mice. Cancer Lett. 104(1): $79-84$

WHO (1992) WHO laboratory manual for the examination of human semen and semen-cervical mucus interaction. Cambridge University Press

Wing T-Y and Christiansen AK (1982) Morphometric studies on rat seminiferous tubule. Am. J. Anat. 165: 13-25

Winter JSD, Faiman C, Hobson WC, Prasad AV and Reyes FI (1975) Pituitarygonadal relations in infancy. I. Patterns of serum gonadotropin concentrations from birth to four years of age in man and chimpanzee. J. Clin. Endocrinol. Metab. 40: $545-551$ 